Archive for

Organic Chemistry

Arkivoc 2017, part v, 10-19

\title{
An efficient stereoselective synthesis of a sulfur-bridged analogue of bosseopentaenoic acid as a potential antioxidant agent
}

\author{
Yasser M. A. Mohamed*a and Eirik Johansson Solum ${ }^{b}$ \\ a Photochemistry Department, National Research Center, Dokki, Giza 12622, Egypt \\ ${ }^{b}$ Faculty of Health Sciences, NORD University, 7800 Namsos, Norway \\ E-mail: y.m.a.mohamed@outlook.com
}

Received 03-07-2017

Accepted 05-06-2017

Published on line 06-25-2017

\section{Abstract}

An efficient approach to the stereoselective synthesis of a novel sulfur-bridged analogue of bosseopentaenoic acid (BPA) by employing the Z-selective modified Boland semi-reduction procedure as the key step is described. The free radical scavenging potential of the thiophene analogue of bosseopentaenoic acid is studied. The results showed that the thiophene ring led to increased antioxidant activity.

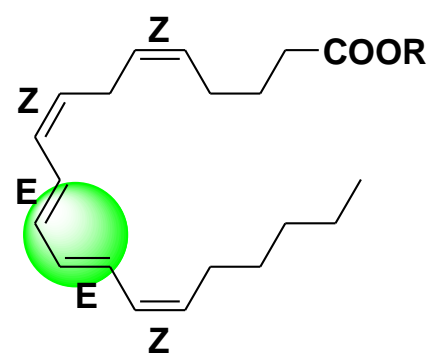

5 a $R=H$ $5 b \mathrm{R}=\mathrm{CH}_{3}$
Rigidification of $E, E$-double bonds by introduction of thiophene moiety to BPA structure

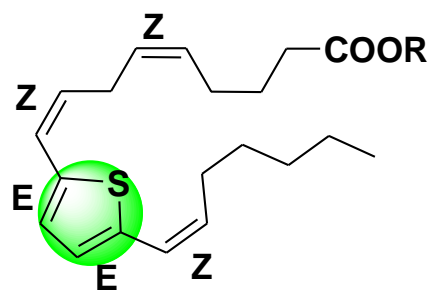

6a: $\mathrm{R}=\mathrm{H}$

6b: $\mathrm{R}=\mathrm{CH}_{3}$

Keywords: Bosseopentaenoic acid, sulfur-bridged, thiophene analogue, antioxidant activity 


\section{Introduction}

Polyunsaturated fatty acids (PUFAs) are a class of compounds, which have gained interest due to an array of beneficial health effects as dietary supplements. ${ }^{1-3}$ In physiological systems, $\omega-3$ and $\omega-6$ fatty acids, like eicosapentaenoic acid (EPA), docosahexaenoic acid (DHA) and arachidonic acid, are mostly esterified to the phospholipid cell membrane.

Once PUFAs are released from the membrane they can participate in signal transduction, either directly or after enzymatic conversion to a variety of important, bioactive lipid mediators. ${ }^{4}$ In several studies the consumption of polyunsaturated fatty acids have shown positive health effects like reducing the risk of cardiovascular diseases ${ }^{5,6}$ and heart attack, ${ }^{7}$ positively associated with cognitive and behavioral performances ${ }^{4,5}$ as well as different types of cancer. ${ }^{6,7}$

The promising biological effects as well as the complex chemical structures of the polyunsaturated fatty acids have made them interesting synthetic targets as well as lead compounds for medicinal chemists. Several attempts have been made to modify the PUFA structures, to improve or modify their biological activities, as well as to simplify the chemical synthesis. In 1985, Corey et al. substituted the methylene group at 7-position in arachidonic acid with sulfur. ${ }^{8}$ The resulting compound 1 possessed inhibitory activity for 5-lipoxygenase (5LO). Later, Hanko et al. synthesized and tested for 5-LO inhibition several analogues of arachidonic acid containing a sulfur atom at the 5-position. ${ }^{9}$ Structure-activity studies suggested the sulfur atom preferably should be attached to E-alkene as in compound $\mathbf{2}$ which was the most active 5-LO inhibitor of those tested in this study. In 2007, Skatteb $\varnothing$ l et al. ${ }^{10}$ reported the synthesis of several thiophene-containing PUFAs such as compounds $\mathbf{3}$ and $\mathbf{4}$ (Figure 1).

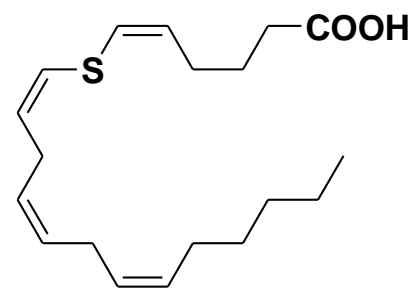

1

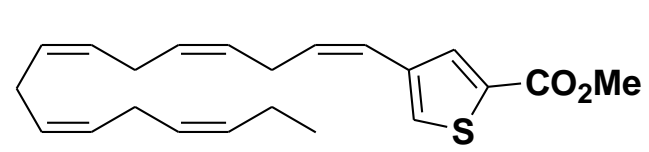

3

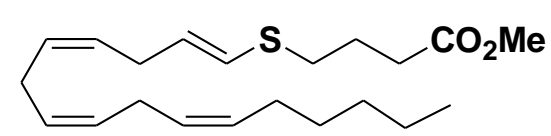

2

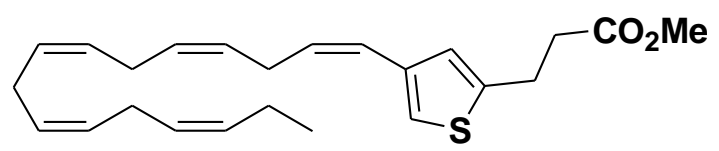

4

Figure 1. Chemical structures of biological active sulfur-containing PUFAs.

From the aforementioned results, it is worth noting that the introduction of sulfur-bridged atom to polyunsaturated fatty acids (PUFAs) is an approach which has received great interest in enhancement of biological effects. Hence, we envisaged to synthesize a rigidified analogue of bosseopenteanoic acid 6a by replacement the two conjugated E,E-double bonds existed in bosseopentaenoic acid 5 a to thiophene moiety and testing their antioxidant activity (Figure 2). 


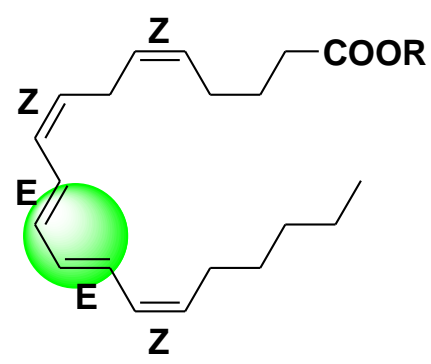

5a $R=H$ $5 b \mathrm{R}=\mathrm{CH}_{3}$
Rigidification of $E$, $E$-double bonds by introduction of thiophene moiety to BPA structure

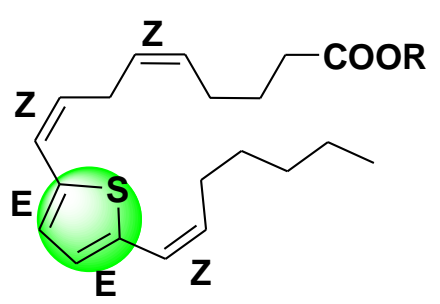

6a: $\mathrm{R}=\mathrm{H}$

6b: $\mathrm{R}=\mathrm{CH}_{3}$

Figure 2. Chemical structure of bosseopentaenoic acid (BPA) 5a, the thiophene analogue of BPA 6 a and the corresponding esters $\mathbf{5 b}$ and $\mathbf{6 b}$.

Bosseopentaenoic acid (BPA) 5a is a naturally occurring $\omega-6$ fatty acid which containing four conjugated double bonds with $Z, E, E, Z$-configuration respectively and one skipped double bond with Z-configuration. The compound was isolated from the red alga Bossiella orbigniana by Burgess et al. in $1991,{ }^{11}$ and the first total synthesis of methyl bosseopentaenoate $\mathbf{5 b}$ was published in $2011 .^{12}$ Herein, we report a synthetic strategy towards a thiophene analogue of BPA 6 a as well as its biological activity evaluation in comparison with BPA 5a.

\section{Results and Discussion}

\section{Chemistry}

A retrosynthetic analysis of the polyunsaturated thiophene is outlined in Figure 3 . The triyne 7 is the key intermediate in the synthesis of the target molecule 6 a. The compound 7 can be converted to 6 a by Zstereoselective semi-reduction of the three triple bonds to corresponding three cis-double bonds followed by hydrolysis of ester group to acid. In the described retrosynthetic pathway, the commercially available 2iodothiophene $\mathbf{1 1}$ was selected to be as starting material in the synthesis of thiophene analogue of bosseopentaenoic acid 6a (Figure 3).

Our synthetic strategy started with the preparation of compound $\mathbf{1 3}$ from the reaction of 2-iodothiophene (15) with hept-1-yne (14) to produce compound $\mathbf{1 3}$ in $88 \%$ yield. This compound was reacted with lithium

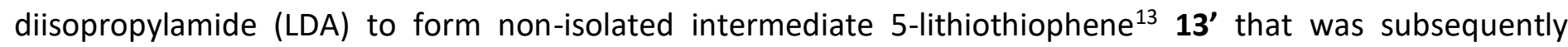
reacted with iodine to form 2-(hept-1-yn-1-yl)-5-iodothiophene (11) in 53\% yield. A Sonogashira coupling ${ }^{14}$ between compound $\mathbf{1 1}$ and propargyl alcohol 12 afforded compound $\mathbf{1 0}$ in $86 \%$ yield. Conversion of this alcohol 10 to corresponding bromide was performed using carbon tetrabromide and triphenyl phosphine at room temperature ${ }^{15,16}$ to obtain compound 8 in $77 \%$ yield. The ${ }^{1} \mathrm{H}$ NMR analysis of compound 8 showed a singlet at $\delta 4.39 \mathrm{ppm}$, characteristic for $\mathrm{CH}_{2}-\mathrm{Br}$. Triyne 7 was achieved in good yield (71\%) through a skipped alkyne synthesis by coupling propargyl bromide 8 with methyl 5-hexynoate 9. ${ }^{17,18} \mathrm{~A}$ Z-stereoselective semireduction of triyne 7, was carried out via a modified Boland protocol using $\mathrm{Zn}(\mathrm{Cu} / \mathrm{Ag})$ in presence of trimethylsilyl chloride (TMSCl$)^{19,20}$ at room temperature, to produce compound $\mathbf{6 b}$ in $65 \%$ yield. The modified Boland protocol, using $\mathrm{Zn}(\mathrm{Cu} / \mathrm{Ag})$ in presence of $\mathrm{TMSCl}$, proved to be important for this reaction ${ }^{12,20-23}$ (Scheme 1); the same reduction carried out with a Lindlar catalyst resulted in a complex mixture of products. ${ }^{24}$ 


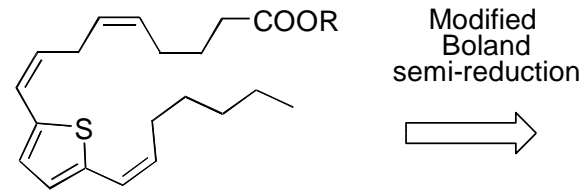

6a, $\mathrm{R}=\mathrm{H}$

6b, $\mathrm{R}=\mathrm{CH}_{3}$

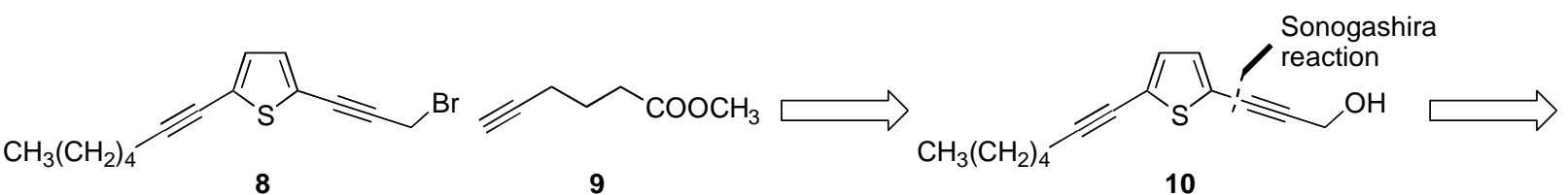

8

9

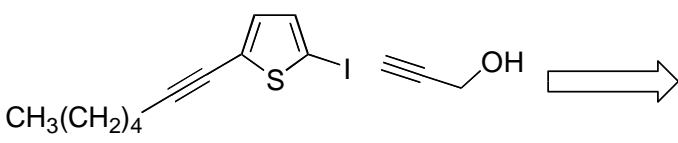

11

12

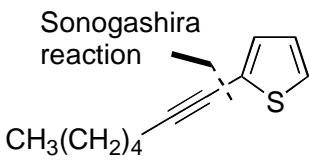

13

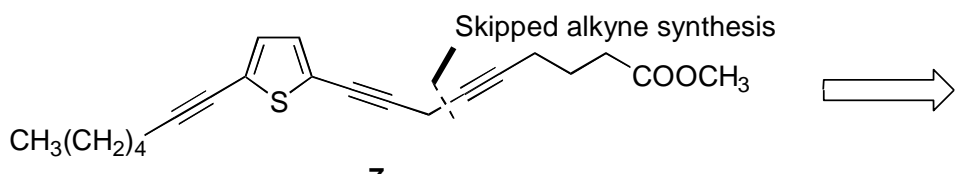

7
10

Figure 3. Retrosynthetic analysis of sulfur-bridged analogue of bosseopentaenoic acid $\mathbf{6 a}$.
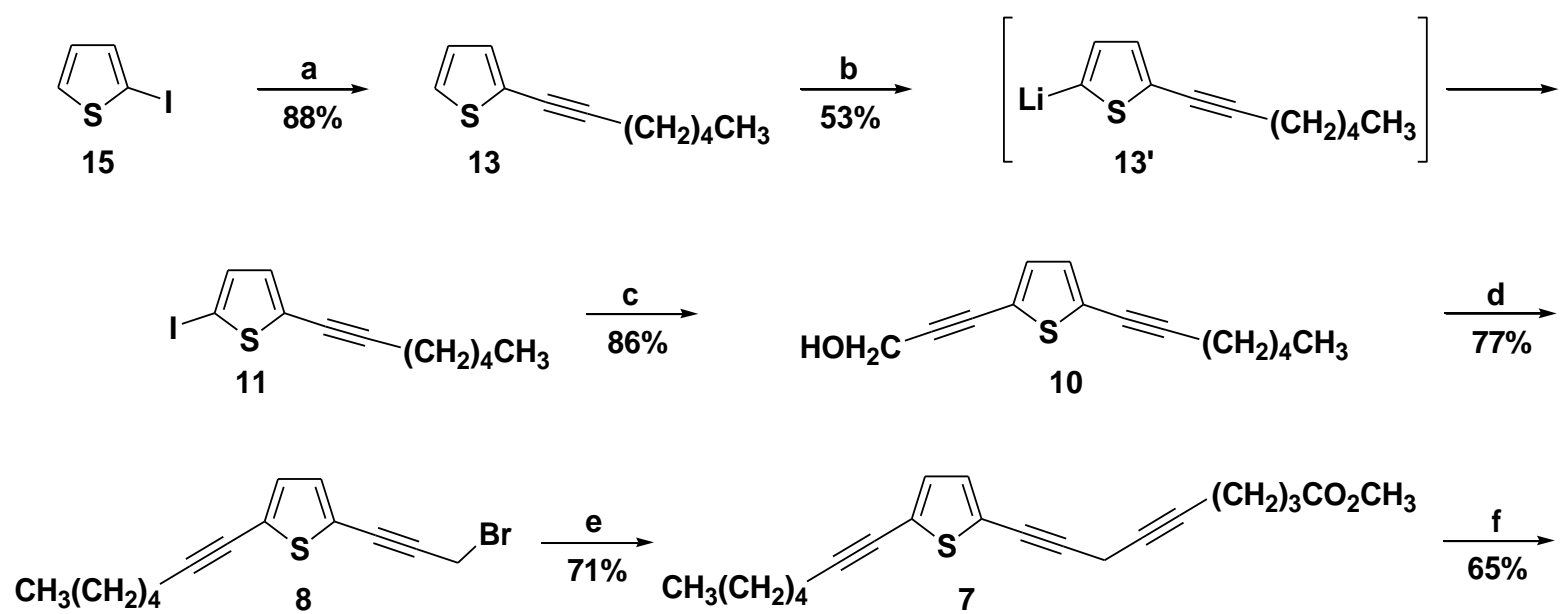

$\left(\mathrm{CH}_{2}\right)_{3} \mathrm{CO}_{2} \mathrm{CH}_{3}$

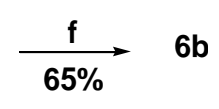

Scheme 1. Reagents and reaction conditions: a) $\mathrm{Pd}\left(\mathrm{Ph}_{3} \mathrm{P}\right)_{2} \mathrm{Cl}_{2}$ (5 mol\%) Cul (10 mol\%), 1-heptyne (14), THF, room temperature; $3 \mathrm{~h}$; b) LDA, $\mathrm{I}_{2}, \mathrm{THF},-40{ }^{\circ} \mathrm{C}, 1 \mathrm{~h}$; c) $\mathrm{Pd}\left(\mathrm{Ph}_{3} \mathrm{P}\right)_{2} \mathrm{Cl}_{2}$ (5 mol\%) Cul (10 mol\%), propargyl alcohol (12), $\mathrm{THF}$, room temperature, $3 \mathrm{~h}$; d) $\mathrm{CBr}_{4}, \mathrm{PPh}_{3}, \mathrm{CH}_{2} \mathrm{Cl}_{2}$, room temperature, $2 \mathrm{~h}$; e) Methyl hexynoate (9), Cul, $n-\mathrm{Bu}_{4} \mathrm{NBr}, \mathrm{Na}_{2} \mathrm{CO}_{3}, \mathrm{DMF}$, room temperature, $16 \mathrm{~h}$; f) $\mathrm{Zn}(\mathrm{Cu} / \mathrm{Ag}), \mathrm{TMSCl}$, (MeOH: $\left.\mathrm{H}_{2} \mathrm{O}, 1: 1\right)$, room temperature, $6 \mathrm{~h}$.

The hydrolysis of the methyl ester $\mathbf{6 b}$ using $\mathrm{LiOH}$, provided the corresponding acid $\mathbf{6 a}$ in $62 \%$ isolated yield. An alternative milder and potentially higher yielding procedure for the hydrolysis of ester group existed in the sensitive substrate by the use of a lithium salt was considered. ${ }^{25}$ However, in our case the reaction did not proceed when the ester $\mathbf{6} \mathbf{b}$ was treated with 10 equivalents of Lil in THF/ $\mathrm{H}_{2} \mathrm{O}$ (3:1) at room temperature for $24 \mathrm{~h}$. In addition, the use of triethylamine with Lil gave a low conversion to the carboxylic acid 6a. From these results, we decided to investigate a mild and more efficient procedure for the hydrolysis of the methyl ester of the thiophene analogue $\mathbf{6} \mathbf{b}$, as well as methyl bosseopentaenoate $\mathbf{5 b}$ that was prepared according to the reported literature procedures. ${ }^{12}$ Herein, an in situ formation of Lil in a two-step reaction was carried out. The first step is the formation of TMSI by mixing $\mathrm{TMSCl}$ with $\mathrm{KI}$. Then LiOH was added subsequently, to produce 
lithium iodide (Lil) that mediated the hydrolysis of the methyl ester $\mathbf{6 b}$ under mild and efficient conditions to afford acid 6 a after 6 hours in $87 \%$ isolated yield (Scheme 2 ).

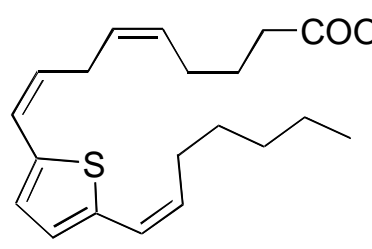

6b

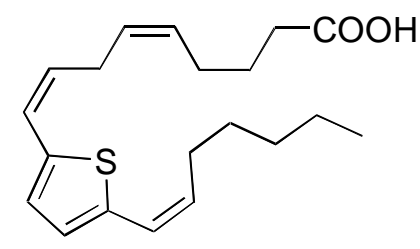

$6 \mathbf{a}$

Scheme 2. Reagents and reaction conditions: a) $\mathrm{LiOH}(6 \mathrm{eq}), \mathrm{MeOH}: \mathrm{H}_{2} \mathrm{O}: \mathrm{THF}(2: 2: 1), 4 \mathrm{~h}$. b) TMSCl (3 eq), $\mathrm{KI}(3$ eq), $\mathrm{LiOH}(3 \mathrm{eq}), \mathrm{MeOH}: \mathrm{H}_{2} \mathrm{O}: \operatorname{THF}(2: 1: 1), 6 \mathrm{~h}$.

The correct configuration of the final compound was assigned by ${ }^{1} \mathrm{H} N M R$ and ${ }^{13} \mathrm{C}$ NMR data. The purity of the thiophene analogue $\mathbf{6 b}$ was determined by HPLC to be $99 \%$. With this procedure, the hydrolysis of the ester group in methyl bosseopentaenoate $\mathbf{5 b}$ was executed. This method provided bosseopentaenoic acid $\mathbf{5 a}$ in $82 \%$ yield. The NMR data of BPA 5 a were in good agreement with those previously reported. ${ }^{11}$

\section{Biological evaluation}

The free radical-scavenging potential of both BPA $\mathbf{5 a}$ and the thiophene analogue $\mathbf{6 a}$ was investigated in a DPPH scavenging assay in comparison with ascorbic acid as standard antioxidant agent. The thiophene analogue 6 a exhibited good radical scavenging activity with $\mathrm{SC}_{50} 5.74 \mu \mathrm{M}$. However, bosseopentaenoic acid $\mathbf{5 a}$ exhibited $\mathrm{SC}_{50} 6.82 \mu \mathrm{M}$ (Table 2).

Table 2. Biological evaluation of the antioxidant activity of thiophene analogue using a DPPH radical scavenging method

\begin{tabular}{cc}
\hline & $\begin{array}{c}\text { Antioxidant activity } \\
\text { DPPH radical scavenging } \\
\text { Compound }\end{array}$ \\
\hline $5 a$ & $6.82 \pm 0.04$ \\
$6 a$ & $5.74 \pm 0.05$ \\
Ascorbic acid & $9.34 \pm 0.07$ \\
\hline${ }^{a}$ Results of three experiments performed in triplicate.
\end{tabular}

Based on these results, both BPA and thiophene analogue have effect in scavenging superoxide. However, the thiophene analogue $6 a$ has the higher susceptibility to oxidation more than BPA 5a dependent on the presence of sulfur-bridged atom in the structure that increased the stability of compound $6 \mathbf{a}$.

\section{Conclusions}

An efficient stereoselective synthesis of a thiophene analogue of bosseopentaenoic acid 6a was achieved in $12 \%$ yield over 7 steps, as well as antioxidant activity were evaluated. The the two $E, E$-double bonds in the 
structure of bosseopentaenoic acid was replaced by thiophene moiety to act as a rigidified analogue of BPA. This replacement resulted in a less flexible structure with fewer rotational options. The key step in our synthetic approach was the Z-selective modified Boland-semi-reduction procedure to establish the three Zdouble bonds in one reaction. The biological evaluation revealed the thiophene analogue $6 \mathbf{6}$ exhibited an improved antioxidant activity compared to the lead bosseopentaenoic acid $\mathbf{5 a}$.

\section{Experimental Section}

General. All reagents and solvents were used as purchased without further purification. Analytical TLC was performed on silica gel 60 F254 Aluminium sheets (Merck). Flash column chromatography was performed on silica gel 60 (40-60 $\mu \mathrm{m}$, Fluka). NMR spectra were recorded on a Bruker Avance DPX spectrometer at 300 or at $400 \mathrm{MHz}$ for ${ }^{1} \mathrm{H}$ NMR, 75 or $101 \mathrm{MHz}$ for ${ }^{13} \mathrm{C}$ NMR respectively. Coupling constants $(J)$ are reported in hertz, and chemical shifts are reported in ppm $(\delta)$ relative to $\mathrm{CDCl}_{3}\left(7.24 \mathrm{ppm}\right.$ for ${ }^{1} \mathrm{H}$ and $77.40 \mathrm{ppm}$ for $\left.{ }^{13} \mathrm{C}\right)$. The HPLC analyses were performed using a Agilent Technologies 1200 Series with an Eclipse XD 8-C18 $5 \mu \mathrm{m}$, 4.6x150 mm column. High-resolution mass (ESI-MS) spectra were measured on (TOF) LC/MS; 6230 Series Accurate-Mass Time-of-Flight.

2-(hept-1-yn-1-yl)thiophene (13). To a mixture of $\mathrm{Pd}\left(\mathrm{Ph}_{3} \mathrm{P}\right)_{2} \mathrm{Cl}_{2}(0.33 \mathrm{~g}, 0.48 \mathrm{mmol}, 5 \mathrm{~mol} \%)$ and $\mathrm{Cul}(0.18 \mathrm{~g}$, $0.95 \mathrm{mmol}, 10 \mathrm{~mol} \%)$ in THF $(5 \mathrm{~mL})$ under nitrogen, piperidine $(2.8 \mathrm{~mL}, 28.56 \mathrm{mmol}, 3$ eq) and 2iodothiophene (15) ( $2 \mathrm{~g}, 9.52 \mathrm{mmol}, 1 \mathrm{eq})$ were added, followed by the addition of 1-heptyne (14) $(0.91 \mathrm{~g}, 9.52$ $\mathrm{mmol}, 3 \mathrm{eq})$. The reaction mixture was allowed to stir for $3 \mathrm{~h}$ at room temperature. The resulting mixture was diluted with EtOAc $(10 \mathrm{~mL})$ then filtered through short pad of silica gel using EtOAc $(30 \mathrm{~mL})$ as eluent. The solution was washed with saturated ammonium chloride, dried $\left(\mathrm{MgSO}_{4}\right)$ and evaporated under reduced pressure. The resulting crude product was purified by column chromatography (silica gel, hexane/EtOAc, $90: 10)$ to afford the title product as a colorless oil $(1.49 \mathrm{~g}, 88 \%) .{ }^{1} \mathrm{H} \mathrm{NMR}\left(300 \mathrm{MHz}, \mathrm{CDCl}_{3}\right): \delta 7.20(\mathrm{~d}, J 6.2 \mathrm{~Hz}$, $1 \mathrm{H}), 7.04-6.91(\mathrm{~m}, 2 \mathrm{H}), 2.44(\mathrm{t}, J \mathrm{7} .1,2 \mathrm{H}), 1.61-1.58(\mathrm{~m}, 2 \mathrm{H}), 1.33-1.25(\mathrm{~m}, 4 \mathrm{H}), 0.87(\mathrm{t}, J 8.6 \mathrm{~Hz}, 3 \mathrm{H}) .{ }^{13} \mathrm{C} \mathrm{NMR}$ $\left(75 \mathrm{MHz}_{1} \mathrm{CDCl}_{3}\right): \delta 132.6,131.4,126.0,125.3,122.6,95.8,97.1,31.5,29.8,22.5,14.3$. HRMS calcd. for $\mathrm{C}_{11} \mathrm{H}_{15} \mathrm{~S}$ $[\mathrm{M}+\mathrm{H}]^{+} 179.0850$, found $[\mathrm{M}+\mathrm{H}]^{+} 179.0841$.

2-(hept-1-yn-1-yl)-5-iodothiophene (11). A solution of lithium diisopropylamide (LDA) (1.0 M in THF/hexane, $0.71 \mathrm{~mL}, 7.09 \mathrm{mmol}, 1.05 \mathrm{eq})$ in THF $(20 \mathrm{~mL})$ was cooled to $-40{ }^{\circ} \mathrm{C}$ and 2-(hept-1-yn-1-yl)thiophene (13) (1.20 g, $6.74 \mathrm{mmol}, 1 \mathrm{eq})$ was added with stirring. After $10 \mathrm{~min}$ the mixture was warmed to $-10{ }^{\circ} \mathrm{C}$ and stirred for approximately $10 \mathrm{~min}$. The mixture was re-cooled to $-40^{\circ} \mathrm{C}$ and iodine $(1.80 \mathrm{~g}, 7.09 \mathrm{mmol}, 1.05 \mathrm{eq})$ was added in one portion. The reaction mixture was allowed to stir for $1 \mathrm{~h}$ and then it was warmed slowly to $0{ }^{\circ} \mathrm{C}$ and saturated $\mathrm{NH}_{4} \mathrm{Cl}$ solution $(5 \mathrm{~mL})$ was added. After extraction with $\mathrm{Et}_{2} \mathrm{O}$, the combined extracts were dried with $\mathrm{MgSO}_{4}$ and the solvent was evaporated. The resulting crude product was purified by column chromatography (silica gel, hexane) to afford the title product as a colorless oil $(1.08 \mathrm{mg}, 53 \%) .{ }^{1} \mathrm{H} \mathrm{NMR}\left(300 \mathrm{MHz}, \mathrm{CDCl}_{3}\right): \delta 7.05$ (d, J $3.8 \mathrm{~Hz}, 1 \mathrm{H}), 6.94(\mathrm{~d}, J 3.8 \mathrm{~Hz}, 1 \mathrm{H}), 2.40(\mathrm{t}, J 7.1 \mathrm{~Hz}, 2 \mathrm{H}), 1.58-1.56(\mathrm{~m}, 2 \mathrm{H}), 1.39-1.27(\mathrm{~m}, 4 \mathrm{H}), 0.89$ (t, J 7.1 $\mathrm{Hz}, 3 \mathrm{H}) .{ }^{13} \mathrm{C} \mathrm{NMR}\left(75 \mathrm{MHz}, \mathrm{CDCl}_{3}\right): \delta 132.5,131.0,126.4,122.5,96.3,73.6,31.5,28.5,22.5,20.1,14.3$. HRMS calcd. for $\mathrm{C}_{11} \mathrm{H}_{14} \mathrm{SI}[\mathrm{M}+\mathrm{H}]^{+} 304.9860$, found $[\mathrm{M}+\mathrm{H}]^{+} 305.1094$.

3-(5-(Hept-1-yn-1-yl)thiophen-2-yl)prop-2-yn-1-ol (10). To a mixture of $\mathrm{Pd}\left(\mathrm{Ph}_{3} \mathrm{P}\right)_{2} \mathrm{Cl}_{2}$ (103 $\mathrm{mg}, 0.17 \mathrm{mmol}, 5$ mol\%) and Cul (57 mg, $0.33 \mathrm{mmol}, 10 \mathrm{~mol} \%)$ in THF $(5 \mathrm{~mL})$ under nitrogen, piperidine $(0.875 \mathrm{ml}, 9.87 \mathrm{mmol}, 3$ eq) and 2-(hept-1-yn-1-yl)-5-iodothiophene (11) (1.0 g, $3.29 \mathrm{mmol}, 1 \mathrm{eq})$ were added, followed by the addition 
of propargyl alcohol (12) (497 mg, $3.29 \mathrm{mmol}, 1 \mathrm{eq})$. The reaction mixture was allowed to stir for $3 \mathrm{~h}$ at room temperature. The resulting mixture was diluted with EtOAc $(10 \mathrm{~mL})$ then filtered through short pad of silica gel using EtOAc $(30 \mathrm{~mL})$ as eluent. The solution was washed with saturated ammonium chloride, dried $\left(\mathrm{MgSO}_{4}\right)$ and evaporated under reduced pressure. The resulting crude product was purified by column chromatography (silica gel, hexane/EtOAc, 90:10) to afford the title product as a colorless oil $(1.5 \mathrm{~g}, 86 \%) .{ }^{1} \mathrm{H} \mathrm{NMR}(300 \mathrm{MHz}$, $\left.\mathrm{CDCl}_{3}\right): \delta 7.01(\mathrm{~d}, J 3.8 \mathrm{~Hz}, 1 \mathrm{H}), 6.89(\mathrm{~d}, J 3.8 \mathrm{~Hz}, 1 \mathrm{H}), 4.49(\mathrm{~s}, 2 \mathrm{H}), 2.42(\mathrm{t}, J 7.1 \mathrm{~Hz}, 2 \mathrm{H}), 1.59-1.56(\mathrm{~m}, 2 \mathrm{H}), 1.44-$ $1.23(\mathrm{~m}, 4 \mathrm{H}), 0.89(\mathrm{t}, \mathrm{J} 7.1 \mathrm{~Hz}, 3 \mathrm{H}) .{ }^{13} \mathrm{C} \mathrm{NMR}\left(75 \mathrm{MHz}, \mathrm{CDCl}_{3}\right): \delta 132.5,131.1,126.4,122.5,96.2,91.6,79.2,73.6$, 52.1, 31.4, 28.5, 22.6, 20.1, 14.3. HRMS calcd. for $\mathrm{C}_{14} \mathrm{H}_{17} \mathrm{OS}[\mathrm{M}+\mathrm{H}]^{+} 233.1000$, found $[\mathrm{M}+\mathrm{H}]^{+} 233.0897$.

2-(3-bromoprop-1-yn-1-yl)-5-(hept-1-yn-1-yl)thiophene (8). To a stirred solution of 3-(5-(hept-1-yn-1yl)thiophen-2-yl)prop-2-yn-1-ol (10) (1 g, $4.31 \mathrm{mmol}$ ) and $\mathrm{CBr}_{4}(1.57 \mathrm{~g}$, $4.74 \mathrm{mmol}$ ) in dichloromethane (30 mL) at $0{ }^{\circ} \mathrm{C}, \mathrm{Ph}_{3} \mathrm{P}(1.36 \mathrm{~g}, 5.17 \mathrm{mmol})$ was added. The reaction mixture was stirred at room temperature for $3 \mathrm{~h}$. The mixture was concentrated under vacuum to obtain a brown oil and quickly added to hexane with stirring $(100 \mathrm{~mL})$. The triphenylphosphine oxide $\left(\mathrm{Ph}_{3} \mathrm{PO}\right)$ was formed as a white precipitate and filtered off. The filtered solution was concentrated under reduced pressure using a rotary evaporator and then purified by flash column chromatography (silica gel, hexane) yielding compound 8 as colorless oil (0.98 g, $77 \%) .{ }^{1} \mathrm{H} \mathrm{NMR}$ $\left(300 \mathrm{MHz} \mathrm{CDCl}_{3}\right): \delta(\mathrm{ppm}) 7.01(\mathrm{~s}, 2 \mathrm{H}), 4.39(\mathrm{~s}, 2 \mathrm{H}), 2.39(\mathrm{t}, J \mathrm{~J} .4 \mathrm{~Hz}, 2 \mathrm{H}), 1.59-1.56(\mathrm{~m}, 2 \mathrm{H}), 1.44-1.23(\mathrm{~m}, 4 \mathrm{H})$, 0.89 (t, J $6.8 \mathrm{~Hz}, 3 \mathrm{H}) .{ }^{13} \mathrm{C} \mathrm{NMR}\left(75 \mathrm{MHz}, \mathrm{CDCl}_{3}\right) \delta 132.5,131.0,126.4,122.5,96.3,91.6,79.2,73.6,47.1,31.5$, 28.5, 22.5, 20.0, 14.3. HRMS calcd. for $\mathrm{C}_{14} \mathrm{H}_{16} \mathrm{BrS}[\mathrm{M}+\mathrm{H}]^{+} 295.0156$ found $[\mathrm{M}+\mathrm{H}]^{+} 295.0152$.

Methyl-9-(5-(hept-1-yn-1-yl)thiophen-2-yl)nona-5,8-diynoate (7). To a mixture of $\mathrm{Na}_{2} \mathrm{CO}_{3}(0.36 \mathrm{~g}, 3.38 \mathrm{mmol}$, $1.5 \mathrm{eq})$, Cul $(0.43 \mathrm{~g}, 2.26 \mathrm{mmol}, 1 \mathrm{eq}), \mathrm{n}-\mathrm{Bu}{ }_{4} \mathrm{NBr}(0.18 \mathrm{~g}, 0.68 \mathrm{mmol}, 0.3 \mathrm{eq})$ in DMF (10 mL) at $-20{ }^{\circ} \mathrm{C}, 5-\mathrm{methyl}$ hexynoate (9) $(0.28 \mathrm{~g}, 2.26 \mathrm{mmol}, 1 \mathrm{eq})$ was added, followed by addition of propargyl bromide 8 (0.80 g, 2.71 $\mathrm{mmol}, 1.2 \mathrm{eq})$. The reaction was allowed to stir at room temperature overnight. $\mathrm{Et}_{2} \mathrm{O}(5 \mathrm{~mL})$ was added, and the resulted precipitate was filtered through a short pad of silica gel. Water $(10 \mathrm{~mL})$ was added to form an aqueous layer which was extracted with $\mathrm{Et}_{2} \mathrm{O}(3 \times 25 \mathrm{~mL})$. The organic layer was washed with saturated ammonium chloride and dried over $\mathrm{MgSO}_{4}$. The solvent was evaporated and the residue was purified by column chromatography (silica gel, hexane/EtOAc, 95:5). The title compound was isolated as colorless oil, which soon turned to yellow, in $71 \%$ yield (0.65 g). $\left.{ }^{1} \mathrm{H} \mathrm{NMR} \mathrm{(300} \mathrm{MHz,} \mathrm{CDCl} 3\right): \delta(\mathrm{ppm}) 7.00(\mathrm{~s}, 2 \mathrm{H}), 3.62(\mathrm{~s} .3 \mathrm{H})$, $2.95(\mathrm{t}, J 6.2 \mathrm{~Hz}, 2 \mathrm{H}), 2.42(\mathrm{t}, J 7.4 \mathrm{~Hz}, 2 \mathrm{H}), 2.38(\mathrm{t}, J 7.4 \mathrm{~Hz}, 2 \mathrm{H}), 2.31-2.13(\mathrm{~m}, 2 \mathrm{H}), 1.69-1.26(\mathrm{~m}, 6 \mathrm{H}), 1.58-1.56$ $(\mathrm{m}, 2 \mathrm{H}), 0.87(\mathrm{t}, J 7.4 \mathrm{~Hz}, 3 \mathrm{H})) .{ }^{13} \mathrm{C} N M R\left(75 \mathrm{MHz}, \mathrm{CDCl}_{3}\right): 176.4,132.8,131.6,130.4,129.6,129.3,129.0,128.9$, 128.7, 128.0, 126.8, 105.4, 100.8, 95.4, 85.2, 84.6, 80.0, 52.1, 33.2, 31.5, 28.5, 24.2, 22.5, 20.1, 18.6, 14.3, 11.2. HRMS calcd. for $\mathrm{C}_{21} \mathrm{H}_{25} \mathrm{O}_{2} \mathrm{~S}[\mathrm{M}+\mathrm{H}]^{+} 341.1475$ found $[\mathrm{M}+\mathrm{H}]^{+} 341.1542$.

Methyl-(5Z,8Z)-9-(5-((Z)-hept-1-en-1-yl)thiophen-2-yl)nona-5,8-dienoate (6b). For Z-selective semi-reduction of the triyne 7 we used the modified Boland procedure. ${ }^{12} \mathrm{The} \mathrm{Zn}(\mathrm{Cu} / \mathrm{Ag})$ was prepared according to reported procedure in literature. ${ }^{19}$ To a suspension of the $\mathrm{Zn}(\mathrm{Cu} / \mathrm{Ag})(2.0 \mathrm{~g})$ in $\mathrm{MeOH}: \mathrm{H}_{2} \mathrm{O}(1: 1,6 \mathrm{~mL})$, the triyne 7 (0.40 $\mathrm{g}, 0.08 \mathrm{mmol}$ ) was added and followed subsequently by the addition of trimethylsilyl chloride (TMSCl) $(0.1 \mathrm{~mL}$, $0.80 \mathrm{mmol}$ ). The reaction mixture was stirred at ambient temperature for $6 \mathrm{~h}$. Upon completion $\mathrm{Et}_{2} \mathrm{O}(5 \mathrm{~mL})$ was added, the reaction mixture was filtered through a short plug of silica gel, and eluted with $\mathrm{Et}_{2} \mathrm{O}(3 \times 5 \mathrm{~mL})$. The combined organic phases were washed with saturated aqueous sodium chloride solution $(10 \mathrm{~mL})$, the organic layer was separated, dried $\left(\mathrm{MgSO}_{4}\right)$, and then removal of the solvent afforded a residue that was purified by column chromatography (silica gel, hexane:EtOAc, 8:2, 7:3, 6:4, 1:1) to afford the desired triene $6 \mathrm{~b}$ in $65 \%$ yield $(0.26 \mathrm{~g}) .{ }^{1} \mathrm{H}$ NMR $\left(300 \mathrm{MHz} \mathrm{CDCl}_{3}\right): \delta 7.05(\mathrm{~s}, 2 \mathrm{H}), 6.11-5.95(\mathrm{~m}, 2 \mathrm{H}), 5.46-5.27(\mathrm{~m}, 4 \mathrm{H}), 3.65(\mathrm{~s}$, 3H), $2.91(t, J 6.2 \mathrm{~Hz}, 2 \mathrm{H}), 2.22(\mathrm{t}, J 7.4 \mathrm{~Hz}, 2 \mathrm{H}), 2.13-2.05(\mathrm{~m}, 4 \mathrm{H}), 1.65(\mathrm{p}, J 7.4 \mathrm{~Hz}, 2 \mathrm{H}), 1.23-1.20(\mathrm{~m}, 6 \mathrm{H}), 0.86$ $(t, J 6.8 \mathrm{~Hz}, 3 \mathrm{H}) .{ }^{13} \mathrm{C} \mathrm{NMR}\left(75 \mathrm{MHz}, \mathrm{CDCl}_{3}\right): \delta 174.0,142.2,139.4,131.4,129.6,129.3,129.0,128.9,125.2$, 
123.7, 122.1, 51.8, 33.8, 31.8, 29.7, 28.3, 26.9, 26.6, 25.1, 22.9, 14.4. HRMS calcd. for $\mathrm{C}_{21} \mathrm{H}_{31} \mathrm{O}{ }_{2} \mathrm{~S}[\mathrm{M}+\mathrm{H}]^{+}$ 347.2045, found $[\mathrm{M}+\mathrm{H}]^{+} 347.2187$.

(5z,8z)-9-(5-((Z)-hept-1-en-1-yl)thiophen-2-yl)nona-5,8-dienoic acid (6a)

Procedure A. The methyl ester $6 \mathrm{~b}(0.10 \mathrm{~g}, 0.29 \mathrm{mmol}, 1 \mathrm{eq}$.) dissolved in THF (1 mL) was transferred to the reaction flask contained $\mathrm{MeOH}: \mathrm{H}_{2} \mathrm{O}(2: 1,3 \mathrm{~mL})$. Solid lithium hydroxide monohydrate $(73 \mathrm{mg}, 1.74 \mathrm{mmol}, 6$ eq.) was added to the reaction mixture at $0{ }^{\circ} \mathrm{C}$ and it was stirred at $0{ }^{\circ} \mathrm{C}$ for $30 \mathrm{~min}$., before the mixture was warmed to room temperature and it was allowed to stir for additional $3 \mathrm{~h}$. The reaction mixture was acidified with saturated aq. $\mathrm{NaH}_{2} \mathrm{PO}_{4}(2 \mathrm{~mL})$. EtOAc $(5 \mathrm{~mL})$ was added and the organic layer was separated. The aqueous layer was followed subsequently by extraction with EtOAc $(2 \times 5 \mathrm{~mL})$. The combined organic layers were dried $\left(\mathrm{MgSO}_{4}\right)$ and concentrated under vacuum. The crude product was purified by flash column chromatography (silica gel, hexane:EtOAc, 7:3, 6:4, 1:1, 3:7, 2:8) to afford thiophene analogue of bosseopentaenoic acid $6 a$ in $62 \%$ yield (59 mg).

Procedure B. A solution of trimethylsilyl chloride (TMSCl) $(0.11 \mathrm{~g}, 0.87 \mathrm{mmol}, 3 \mathrm{eq})$, Potassium iodide (KI) $(0.14$ $\mathrm{g}, 0.87 \mathrm{mmol}, 3 \mathrm{eq})$ in $\mathrm{MeOH}: \mathrm{H}_{2} \mathrm{O}(2: 1, \mathrm{~mL})$ was stirred at room temperature. After 15 min solid lithium hydroxide monohydrate $(12 \mathrm{mg}, 0.29 \mathrm{mmol}, 3 \mathrm{eq})$ dissolved in $\mathrm{H}_{2} \mathrm{O}(1 \mathrm{~mL})$ was added slowly, and the reaction mixture was stirred for additional $30 \mathrm{~min}$. The methyl ester $6 \mathrm{~b}(0.1 \mathrm{~g}, 0.29 \mathrm{mmol})$ dissolved in THF $(1 \mathrm{~mL})$ was added and the resulting mixture was stirred at ambient temperature for $6 \mathrm{~h}$. Upon completion $1 \mathrm{M} \mathrm{Na}_{2} \mathrm{HPO}_{4}(2$ $\mathrm{mL})$ and EtOAc $(2 \mathrm{~mL})$ was added, and the organic layer was separated. The aqueous layer was further extracted with EtOAc $(3 \times 5 \mathrm{~mL})$. The combined organic layers were dried $\left(\mathrm{MgSO}_{4}\right)$ and concentrated under vacuum. The crude product was purified by flash column chromatography (silica gel, hexane:EtOAc, 7:3, 6:4, $1: 1,3: 7,2: 8$ ) to obtain thiophene analogue of bosseopentaenoic acid $6 \mathrm{a}$ in $87 \%$ yield (83 mg). ${ }^{1} \mathrm{H} \mathrm{NMR} \mathrm{(300}$ $\left.\mathrm{MHz}, \mathrm{CDCl}_{3}\right): \delta 12.51(\mathrm{~s}, 1 \mathrm{H}), 7.02(\mathrm{~s}, 2 \mathrm{H}), 6.02-5.97(\mathrm{~m}, 2 \mathrm{H}), 5.48-5.30(\mathrm{~m}, 4 \mathrm{H}), 2.89(\mathrm{t}, J 6.2 \mathrm{~Hz}), 2.16(\mathrm{t}, J 7.5$ $\mathrm{Hz}, 2 \mathrm{H}, 2.16(\mathrm{t}, J 7.5 \mathrm{~Hz}, 2 \mathrm{H}), 2.11-2.05(\mathrm{~m}, 2 \mathrm{H}), 1.66(\mathrm{p}, J 7.5 \mathrm{~Hz}, 2 \mathrm{H}), 1.32-1.20(\mathrm{~m}, 6 \mathrm{H}), 0.88(\mathrm{t}, J 6.8 \mathrm{~Hz}, 3 \mathrm{H})$. ${ }^{13} \mathrm{C}$ NMR $\left(75 \mathrm{MHz}, \mathrm{CDCl}_{3}\right): \delta 180.1,142.3,139.4,131.5$ (2 x C), 129.7, 129.4, 129.1, 128.9, 123.3, 122.0, 33.8, $31.9,29.7,28.3,26.9,26.6,25.2,22.9$, 14.4. HRMS calcd. for $\mathrm{C}_{20} \mathrm{H}_{28} \mathrm{O}_{2} \mathrm{~S}[\mathrm{M}-\mathrm{H}]^{+} 331.1732$, found $[\mathrm{M}-\mathrm{H}]^{+}$ 331.1842. Purity (HPLC) 99\%.

Bosseopentaenoic acid (5a). A solution of TMSCl ( $31 \mathrm{mg}, 0.29 \mathrm{mmol}, 3 \mathrm{eq}), \mathrm{KI}(48 \mathrm{mg}, 0.29 \mathrm{mmol}, 3 \mathrm{eq})$ in $\mathrm{MeOH}: \mathrm{H}_{2} \mathrm{O}(2: 1,3 \mathrm{~mL})$ was allowed to stir at room temperature. After $15 \mathrm{~min}$ solid lithium hydroxide monohydrate $(12 \mathrm{mg}, 0.29 \mathrm{mmol}, 3 \mathrm{eq})$ dissolved in $\mathrm{H}_{2} \mathrm{O}(1 \mathrm{~mL})$ was added slowly, and the reaction mixture was stirred for additional $30 \mathrm{~min}$. The methyl bosseopentaenoate $5 \mathrm{~b}(30 \mathrm{mg}, 0.096 \mathrm{mmol}$ ) dissolved in THF (1 $\mathrm{mL}$ ) was added and the resulting mixture was stirred at ambient temperature for $6 \mathrm{~h}$. Upon completion $1 \mathrm{M}$ $\mathrm{Na}_{2} \mathrm{HPO}_{4}(2 \mathrm{~mL})$ and EtOAc $(2 \mathrm{~mL})$ was added, and the organic layer was separated. The aqueous layer was further extracted with EtOAc $(3 \times 5 \mathrm{~mL})$. The combined organic layers were dried $\left(\mathrm{MgSO}_{4}\right)$ and concentrated under vacuum. The crude product was purified by flash column chromatography (silica gel, hexane: EtOAc, $7: 3,6: 4,1: 1,3: 7,2: 8)$ to obtain bosseopentaenoic acid 5a in $82 \%$ yield $(24 \mathrm{mg})$. Spectroscopic and physical data were in agreement with those reported in the literature. ${ }^{1} \mathrm{H} \mathrm{NMR}\left(300 \mathrm{MHz}, \mathrm{CDCl}_{3}\right): \delta 6.49$ (dd, $J$ 13.4, $10.8 \mathrm{~Hz}, 2 \mathrm{H}), 6.16-6.42(\mathrm{~m}, 2 \mathrm{H}), 5.25-5.48(\mathrm{~m}, 4 \mathrm{H}), 2.89(\mathrm{t}, J 7.4 \mathrm{~Hz}, 2 \mathrm{H}), 2.13(\mathrm{q}, J 7.4 \mathrm{~Hz}, 2 \mathrm{H}), 2.05(\mathrm{t}, J 7.4 \mathrm{~Hz}$, 2H), $1.54(p, J 7.4 \mathrm{~Hz}, 2 \mathrm{H}), 1.21-1.91(\mathrm{~m}, 6 \mathrm{H}), 0.88(\mathrm{t}, J 6.8 \mathrm{~Hz}, 3 \mathrm{H}) .{ }^{13} \mathrm{C} \mathrm{NMR}\left(75 \mathrm{MHz}, \mathrm{CDCl}_{3}\right): \delta$ 180.0, 133.6, 133.0, 132.1, 129.9, 129.2, 129.0, 128.6, 128.4, 127.0, 126.5, 32.8, 31.3, 29.0, 27.9, 26.3, 26.2, 24.3, 22.6, 13.9. HRMS calcd. for $\mathrm{C}_{20} \mathrm{H}_{30} \mathrm{O}_{2}[\mathrm{M}+\mathrm{Na}]^{+} 325.2099$, found $[\mathrm{M}+\mathrm{Na}]^{+} 325.2038$. Purity (HPLC) $98 \%$. The NMR spectra was consistent with the published data. ${ }^{11}$

\section{Antioxidant activity DPPH scavenging assay}

To investigate the antioxidant activity an 1,1-diphenyl-2-picrylhydrazyl (DPPH) scavenging assay was used. Various concentrations of the compounds $(0.1-50 \mu \mathrm{g} / \mathrm{mL})$ were prepared in $\mathrm{MeOH}$. The solution $(1.0 \mathrm{~mL})$ was 
added to $1.0 \mathrm{~mL}(0.2 \mathrm{mg} / \mathrm{mL})$ methanol solution of DPPH and kept in dark. The decrease in absorbance at 517 $\mathrm{nm}$ was observed after $30 \mathrm{~min}$. The percentage scavenging of radical was determined and the results were expressed as the concentration of sample where absorbance of DPPH decreases $50 \%$ (SC $\mathrm{S}_{50}$ values, $\mu \mathrm{M}$ ). ${ }^{26}$

\section{Acknowledgements}

We are grateful to the National Research Center (Egypt) and NORD University (Norway) for providing the facilities. Also, the authors would like to thank Prof. Dr. Trond Vidar Hansen for his support and valuable discussions.

\section{References}

1. Endres, S.; Ghorbani, R.; Kelley, V. E.; Georgilis, K.; Lonnemann, G.; van der Meer, J. W. M.; Cannon, J. G.; Rogers, T. S.; Klempner, M. S.; Weber, P. C.; Schaefer, E. J.; Wolff, S. M.; Dinarello, C. A. New England J. Med. 1989, 320, 265-271.

https://doi.org/10.1056/NEJM198902023200501

2. Hansen, T. V.; Dalli, J.; Serhan, C. N. RSC Adv. 2016, 6, 28820-28829.

https://doi.org/10.1039/C6RA00414H

3. Chen, G.-C.; Yang J.; Eggersdorfer, M.; Zhang, W.; Qin, L.-Q. Scientific Reports 2016, 6, 28165. https://doi.org/10.1038/srep28165

4. Wenzel, S. E. Pharmacotherapy: The Journal of Human Pharmacology and Drug Therapy, 1997, 17, 3S$12 S$.

5. Al-Khudairy, L.; Hartley, L.; Clar, C.; Flowers, N.; Hooper, L., Rees, K. Cochrane Database Syst. Rev. 2015, https://doi.org/10.1002/14651858.CD011094.pub2

6. Willett, W. C. J Cardiovasc Med. 2007, 8, S42-S45. https://doi.org/10.2459/01.JCM.0000289275.72556.13

7. Harris, W.; Current Opin. Clinic. Nutr. Metab. Care 2010, 13, 125-129. https://doi.org/10.1097/MCO.0b013e3283357242

8. Corey, E. J.; Cashman, J. R.; Eckrich, T. M.; Corey, D. R. J. Am. Chem. Soc. 1985, 107, 713-715. https://doi.org/10.1021/ja00289a039

9. Hanko, R.; Hammond, M. D.; Fruchtmann, R.; Pfitzner, J.; Place, G. A. J. Med. Chem. 1990, 33, 1163-1170. https://doi.org/10.1021/jm00166a013

10. Flock, S.; Holmeide, A. K.; Skattebøl, L. Synth. Commun. 2007, 37, 4005-4015. https://doi.org/10.1080/00397910701575053

11. Burgess, J. R.; de la Rosa, R. I.; Jacobs, R. S.; Butler, A. Lipids 1991, 26, 162-165. https://doi.org/10.1007/BF02544012

12. Mohamed, Y. M. A.; Hansen, T. V. Tetrahedron Lett. 2011, 52, 1057-1059. https://doi.org/10.1016/i.tetlet.2010.12.078

13. De Sousa, P. T.; Taylor, R. J. K. Synlett 1990, 755-757. https://doi.org/10.1055/s-1990-21240

14. Sonogashira K. J. Organometal. Chem. 2002, 653, 46-49. 
15. Appel, R. Angew. Chem. Int. Ed. Engl. 1975, 14, 801-811.

https://doi.org/10.1002/anie.197508011

16. Baughman, T. W.; Sworen, J. C.; Wagener, K. B. Tetrahedron 2004, 60, 10943-10948. https://doi.org/10.1016/i.tet.2004.09.021

17. Lapitskaya, M. A.; Vasiljeva, L. L.; Pivnitsky, K. K. Synthesis 1993, 65-66. https://doi.org/10.1055/s-1993-25795

18. Jeffery, T.; Gueugnot, S.; Linstrumelle, G.; Tetrahedron Lett. 1992, 33, 5757-5760. https://doi.org/10.1016/0040-4039(92)89024-7

19. Boland, W.; Schroer, N.; Sieler, C.; Feigel, M.; Helv. Chim. Acta 1987, 70, 1025-1040. https://doi.org/10.1002/hlca.19870700415

20. Mohamed, Y. M. A.; Hansen, T. V. Tetrahedron 2013, 69, 3872-3877. https://doi.org/10.1016/j.tet.2013.03.038

21. Brütsch, T. M.; Bucher, P.; Altmann, K.-H. Chem. Eur. J. 2016, 22, 1292-1300. https://doi.org/10.1002/chem.201504230

22. Dayaker, G.; Durand, T.; Balas, L. J. Org. Chem. 2014, 79, 2657-2665. https://doi.org/10.1021/jo500147r

23. Dayaker, G.; Durand, T.; Balas, L. Chem. Eur. J. 2014, 20, 2879-2887. https://doi.org/10.1002/chem.201304526

24. Avignon-Tropis, M.; Pougny, J. R. Tetrahedron Lett. 1989, 30, 4951-4952. https://doi.org/10.1016/S0040-4039(01)80551-7

25. Mattsson, S.; Dahlström, M.; Karlsson, S. Tetrahedron Lett. 2007, 48, 2497-2499. https://doi.org/10.1016/j.tetlet.2007.02.029

26. Can, Z.; Dincer, B.; Sahin, H.; Baltas, N.; Yildiz, O.; Kolayli, S. J. Enz. Inhib. Med. Chem. 2014, 29, 829-835. https://doi.org/10.3109/14756366.2013.858144 